\title{
A MODEST REFEREE: MEASURING THE UNESCO CCD'S EFFECT ON CULTURE AND FREE TRADE AGREEMENT NEGOTIATION
}

Chantal Braganza

Bachelor of Journalism, Ryerson University, 2009

\author{
A major research paper \\ presented to Ryerson University and York University \\ in partial fulfillment of the requirements for the degree of
}

\author{
Master of Arts \\ in the joint program of \\ Communication and Culture
}

Toronto, Ontario, Canada, 2018

(C) Chantal Braganza, 2018 


\begin{abstract}
Author's Declaration
I hereby declare that I am the sole author of this MRP. This is a true copy of the MRP, including any required final revisions. I authorize Ryerson University to lend this MRP to other institutions or individuals for the purpose of scholarly research. I further authorize Ryerson University to reproduce this MRP by photocopying or by other means, in total or in part, at the request of other institutions or individuals for the purpose of scholarly research. I understand that my MRP may be made electronically available to the public.
\end{abstract}




\title{
A MODEST REFEREE: MEASURING THE UNESCO CCD'S EFFECT ON CULTURE AND FREE TRADE AGREEMENT NEGOTIATION
}

\author{
Chantal Braganza \\ Master of Arts in Communication and Culture \\ Ryerson University, 2018
}

\begin{abstract}
The purpose of this research is to assess the effectiveness of the UNESCO Convention on the Protection and Promotion of Diversity of Cultural Expressions (CCD) as a trade instrument intended to protect local culture and cultural industries from free market influences. Much previous writing has pointed out flaws or weaknesses in its legal language and structure; few studies have been carried out on the way it has been cited and employed in actual trade negotiations and disputes. Through a recount of the its history, a close read of the original document of the CCD itself, and a case-study examination of two recently signed free trade agreements and a concluded international trade dispute, this research paper will show that the ways in which this nearly 15-year-old document has been employed does not quite live up to its intended purpose.
\end{abstract}

Keywords: cultural policy, free trade, UNESCO CCD, culture and trade disputes, cultural diplomacy, CETA, CPTPP 


\section{Table of Contents}

Declaration $\quad$ i

$\begin{array}{lll}\text { Abstract } & \text { ii }\end{array}$

Introduction $\quad 1$

Canadian Cultural Policy: A Background 4

The UNESCO CCD: A Literature Review

$\begin{array}{ll}\text { Theoretical Framework } & 13\end{array}$

$\begin{array}{ll}\text { Research Method and Data } & 15\end{array}$

Case Study One: WTO Dispute Settlement Redux 15

Case Study Two: The Canada-EU Comprehensive 19

Economic Trade Agreement

Case Study Three: The CPPTPP 25

$\begin{array}{ll}\text { Discussion and Conclusion } & 28\end{array}$

$\begin{array}{ll}\text { Works Cited } & 31\end{array}$ 


\section{Introduction}

"It's simply old-fashioned industrial protection really disguised as a cultural policy. And I think what the cultural protectionists are increasingly fighting are not Americans; they're fighting other Canadians, they're fighting Canadian consumers and taxpayers who don't want to pay the direct and indirect costs of these policies." Stephen Harper, The Sunday Report, 1997 (Johnson, 2005, p. 259)

Nine years before he was elected as Canada's prime minister, Stephen Harper, newly resigned from his then-parliamentary seat, sat down for a feature interview with Canadian Broadcasting Corporation reporter Wendy Mesley to discuss his opinion on a controversy that had embroiled national media for months: a bilateral trade battle over American "split-run" magazines and the Canadian cultural policy tools used to protect the domestic magazine market from them. The interview was a telling comment on what was a pivotal moment for Canadian cultural policy.

Neither nightmare scenario of a totalitarian protectionist state nor a homogenized cultural wasteland completely void of the arts and ideas that form Canadian identity seem to have materialized since. Over the course of twenty years we have seen four prime ministers' offices, nine newly in-force free trade agreements (FTAs) and in 2005, the creation of the Convention on the Protection and Promotion of the Diversity of Cultural Expressions (CCD), an agreement by the United Nations Educational, Scientific and Cultural Organization (UNESCO) globally heralded as a 
historic milestone in the co-operation of nations regarding the development of cultural policy.

For Canadian cultural policymakers, the two decades leading up to the creation of the CCD can be characterized as a time of anxiety over what effect the encroaching influence of free trade markets would eventually have over the ability for federal and local governments to identify at-risk sectors of Canadian culture and build cultural policy frameworks to support and protect them.

This fear was shared among a number of like-minded countries worldwide: “On a global level," cultural policy scholar Sarah Armstrong of the World Trade Organization rulings that eventually decided the magazine case, "what is at stake is the ability of national governments to protect culture and cultural industries." (Armstrong, 1999, p. 382) The development and adoption of the CCD, a convention intended to unite the global community in some form of political and legal agreement on the particular and vulnerable nature of culture and cultural industries in the context of free trade, was meant to ameliorate this anxiety and affirm domestic governments' rights to develop local cultural policies that might otherwise be challenged in a trade negotiation setting.

The purpose of this paper is to evaluate what that second element of the UNESCO CCD has or has not done for the development of cultural policy in a global landscape increasingly mediated by liberalized trade and continuously redefined by the widening parameters the digital ecology sets for us. To what extent is the CCD an effective tool in promoting and protecting cultural rights in global trade? 
Based upon commentary from legal and policy scholars published at the time of the CCD's development, which will be expanded upon in the literature review section, the working hypothesis to this research question posits that as a legal tool the CCD cannot prove particularly useful in the act of negotiating and developing international trade agreements. This is due in part to its non-binding nature, its cession to other aspects of trade law in instances of conflict, and the higher likelihood of the latter occurring as nation-states around the globe are brokering free trade agreements with each other bilaterally and in multi-member partnerships with increasing frequency.

Since its signing on to this UNESCO convention, Canada has signed and entered into force more FTAs in the past ten years than the past thirty overall, (Global Affairs Canada, 2017) while simultaneously witnessing a cultural policy landscape emerge one quite different from the one that used to characterize its identity. This study will attempt to evaluate this question.

First, a brief backgrounder will provide the Canadian context of the UNESCO CCD and review the contemporary literature available on commentary regarding its employment as a trade instrument, followed by an explanation of the theoretical framework and research methods to be used. Next, a case-study look at how the CCD has been used in contemporary trade dealings, including free trade agreements and free trade disputes, assessing through original trade agreement documents or proceedings from WTO trade disputes whether current developments in free trade as it relates to the cultural industries live up to the original goal of this UNESCO's convention. Finally, a concluding look at the CCD's shortcomings in treaty-making application will consider 
areas for improvement — or metrics outside of trade law can be considered as a metric for success.

\section{Canadian Cultural Policy: A Background}

Understanding Canada's relationship with the UNESCO CCD requires an understanding of its own history with cultural policy. The CCD's own existence as an international agreement and intended trade tool somewhat relies on it. In her 1994 Robarts Lecture Series, cultural policy scholar and arts administrator Joyce Zemans noted that "[n]ationhood, national identity and cultural defence have, in fact, been at the heart of Canadian policies in support of cultural development as evidenced by the creation of Canada's major national institutions," and that Katz and Cummings'Patron State (1987) — which distinguished between identity-developing versus identitypreserving approaches to cultural policy — "might very well have been drawn from a Canadian case study.” (1997, p. 42)

Looking to the mid-1980s and mid-1990s as a transitional era in foreign cultural policy, Louis Bélanger noted that the early days of the contemporary neoliberal age marked a global shift that affected not only our own approach. Where once foreign policies in the form of market intervention and institution-building represented soft power in cultural influence, the twin pressures of trade liberalization and rapid development of communication technology (and the resulting influence on modes of cultural production) meant a decentralization of the flow of cultural products. "To be culturally powerful — or even culturally significant — in today's world, a country must exert control over these flows," he wrote of the time. (1999, p. 677) 
How did Canada make this shift? Policy is an ongoing product of its context and era; while no single factor can adequately answer this question, one case study is often pointed to as emblematic of the changing landscape Canadian government was operating in at the time: a 1997 trade conflict ruling made by the World Trade Organization's Dispute Settlement Body (WTO, 1998) over tariffs imposed on "splitrun" magazines - foreign publications that undercut Canadian ones by reprinting issues domestically at lower overhead costs, and therefore much lower ad rates than local titles would ever be able to charge. Sarah Armstrong's 1999 recount of the Canada-U.S. split-run magazine saga is an oft-cited text on the history of this case, but a brief overview of the policy framework surrounding this incident is instructive in understanding the country's involvement in the early days of the UNESCO CCD's development and promotion.

In the 1960s, a series of domestic policies were enacted to bolster Canadian magazines, which had for some time struggled to break through in their own markets: tax codes that prohibited shipping split run magazines across the border (Custom Tariff Code 9958); prohibitions of advertisers claiming tax deductions for running ads in magazines with less than 80 per cent Canadian content; boosted postal subsidies (Armstrong, 1999). In The Cultural Industries in Canada, Lon Dubinsky notes that this trifecta worked for Canadian titles well into the late 1970s (1996).

Before long, innovation in communication technology enabled publishers to send digital mockups to printing centres, thus allowing them to circumvent the rules of Custom Tariff Code 9958 entirely (Smith, 1980). In 1990, Time Warner Inc. took 
advantage of this loophole by applying to introduce a split-run edition of its magazine, Sports Illustrated, to the Canadian market this way (Armstrong, 1999).

In response, Canada issued Bill C-103 in 1995 - a stricter tax deduction regulation that would effectively price low-Canadian-content split runs such as Sports Illustrated out of the market. One year earlier, however, Canada had signed on to the terms of the 1994 Uruguay General Agreement of Tariffs and Trade (GATT), and later the North American Free Trade Agreement (NAFTA), and had signed membership with the World Trade Organization (WTO).

Armed with a conflict resolution model whose mechanisms for vaulting cultural industries and the policies that influence that aligned with its more free-market view of both, Washington took Ottawa to the WTO's Settlement Dispute Body over Bill C-103, arguing that the policy was anti-competitive and an infraction of the terms of NAFTA, and did the same with the remaining policy tools Canada had first set in place back in the '60s (Armstrong, 1999). On all counts but commercial postal rates, the WTO's Dispute Settlement Body ruled in favour of the U.S. Less than a year later, when Canada tried to curb funnelling of domestic ad revenue to foreign titles by defining ad rates as a service, not a cultural product, with Bill C-55 in 1998, U.S. government only needed to threaten Ottawa with another WTO hearing to initiate negotiations in favour of their free-trade terms.

The conclusion of this international debate signalled a shift to a new environment in which domestic cultural policy could now be beholden to free trade terms and the trade ideologies of other countries with which Canada was signed (Acheson \& Maule, 1999). International neighbours with similar cultural policy 
heritage or ideologies that had followed this trade conflict with vested interest—such as France, Korea and Japan—were similarly troubled by the result. The shared political mood among this sector of the global community set the stage for the type of international co-operation necessary to make the UNESCO CCD a reality.

\section{The UNESCO CCD: A Literature Review}

The years following have been marked by scholars and journalists alike as a catalyst moment for the country's involvement in global organizing towards cultural diversity rights and federal governments' ability to protect domestic cultural expressions and industries via trade law. As Jody Neathery-Castro notes, "Canada was poised to help spearhead the cultural diversity movement, having just experienced the WTO ruling against its magazine industry" $(2012$, p. 76). Two years after the WTO rulings, then-Canadian Heritage Minister Sheila Copps invited a global network of similarly-minded ministers responsible for national heritage to Ottawa to work towards the development of an international legal mechanism in support of domestic cultural protection and promotion (Conlogue, 2001). The annually-meeting International Network on Cultural Policy (INCP) is considered a large mitigating factor in UNESCO's eventual 2003 decision to develop a convention for such a purpose (Neathery-Castro, 2012).

The uniting fear among CCD-supporting nations at the time of the convention's creation was encroaching culture empiricism, primarily of the United States, and this hegemony has certainly been provable in terms of numbers. Until 2009, the U.S. held top spot as the world's top exporter of cultural goods for years, regularly disseminating 
between $\$ 15$ billion and \$25 billion worth of cultural products from 2004 onwards (UNESCO, 2016). Since that year China has far outstripped the U.S. in terms of export numbers - up to $\$ 60$ billion in 2013, double that of the U.S. in that same year - and though this recent development in the global cultural trade arena likely has a number of implications of its own, the significance here lies in the fact that the next eight top exporting countries in the world, including the United Kingdom, India, Switzerland and Germany, do not even come close to approaching such numbers — and the global influence in both trade and culture that accompanies it (UNESCO, 2016).

The near-global consensus on the need for a convention on protecting cultural industries and expression in an era of free trade was made clear at UNESCO's 31st Assembly, in which 148 member nations voted in favour of developing one, with four abstentions and two votes against — Israel and the United States (UNESCO, 2005). Within two years, the full convention - what we now know as the UNESCO CCD was drafted, proposed, and adopted in October of 2005, to both international fanfare among media outlets hailing the document as a landmark achievement, and disagreement between policy experts over its efficacy (UNESCO, 2008). It was in turns hailed by some as a "Magna Carta for cultural policy," (Sabine \& Stoll, 2012, p. 14) and criticized by others as an "awareness-raising document" with "no enforceable rules" (Acheson \& Maule, 2004, p. 243).

On a closer read the document itself, however, it becomes apparent that the CCD's goals and potential for use fall somewhere in between these polar opposite conceptions of a history-altering charter of rights and toothless list of platitudes. The 35-point convention is wide in scope: it covers definitions of such politically fraught 
concepts of what constitutes culture, or a cultural industry; the rights of signatory parties to protect and promote culture domestically and internationally, and the difference between the actions of protection and promotion; considerations for developing countries particularly vulnerable to cultural globalization; and importantly here, its relationship to other treaties (UNESCO, 2005).

Its goals, as distilled in Article 1, fall under four categories: to establish a level playing field for the development and nurturing of local cultures; to set an international standard of definition for what constitutes a cultural activity, good, or service, and recognize its value beyond the strictly economic; to help facilitate international cooperation in issues regarding the protection and promotion of local culture; and to definitively establish each signatory member states' right to develop and implement relevant domestic policies for such a purpose (UNESCO, 2005).

Within two years of its adoption, fifty-six states and the European Union had joined as signed parties to the agreement; within five, this number rose to more than eighty. As of 2017, 145 parties have signed onto the agreement, making it among the more popularly signed and quickly drafted conventions in UNESCO's seventy-two-year history (Aylett, 2010). Also as of 2017, the CCD had been in force for just shortly over a decade, with Canada among the first 30 states to ratify it. In the ten years since, select aspects of both camps of opinion about the CCD have proven correct. Some signatory states have taken the promotion ideal of the convention to heart, establishing ministries of heritage or national cultural policy programs where there had previously been none: notably Peru, Burkina Faso and the Seychelles (Naoto, 2015). 
Concerns by entertainment industry lobbyists the United States that the Convention would be used as a protectionist policy shield that would shut down trading pathways between nations - then U.S. Secretary of State Condoleezza Rice memorably warned member states that the CCD “will only undermine UNESCO's image and sow confusion and conflict rather than cooperation" - proved far less dire in outcome (Riding, 2005). A 2015 study of trading data on member states to the Convention conducted by the Research Institute of Economy, Trade and Industry found that across the board, import of cultural products, both audiovisual and otherwise, in fact increased and diversified in source countries between 2004 and 2010 (Naoto).

But in terms of the CCD's original intended purpose - a legal instrument to offer member states leeway in protecting local cultural industries while negotiating free trade deals — the outlook among policy experts and scholars has been less than enthusiastic. Similar to Canada's experience with the United States and the WTO in its conflict over magazine tariffs, ideological disagreement between nations in trade versus culture resulted in a compromise that has, arguably, satisfied neither the desires of states invested in cultural diversity, nor made much headway in helping nations on either side of the issue come closer to a middle ground — let alone work on solutions that address how technological advancements are affecting the trade-versus-culture binary.

There is, to start, the construction of its overall language. Articles 7 to 19 , which outline a comprehensive list of rights and actions signatory states "may" or "shall endeavour" to undertake, are weakened in their lack of any concrete obligation placed on the part of the parties for the most part. Article 6, for example, which outlines national rights in regards to taking domestic measures to determine cultural expressions 
at risk and rights to take measures to protect them (UNESCO, 2005), does not explicitly list what might constitute a measure or assign that right any type of authority over the pre-CCD status quo-i.e. presumably that a signatory state may have already done such a thing in the past. Further complicating matters, as Mira Burri-Nenova notes, is the lack of any real course of penalization (2012). Most relevant to the question of international trade, the recourse for conflict resolution in the event of a dispute has similarly been criticized (Hahn, 2006), and rarely in the CCD's near decade since its entry to force been put to use.

Article 20, which outlines the CCD's legal relationship to other international agreements, is a second potential shortcoming. In particular, the stipulation in 20.2: "Nothing in this Convention shall be interpreted as modifying rights and obligations of the Parties under any other treaties to which they are parties" (UNESCO, 2005). In other words, any specific instructions in the CCD that go beyond the scope of rights into outward obligations are still subordinate to any previously ratified international trade agreement that contravenes what it asks.

In his chapter of Governing Global Electronic Networks, Byung-Il Choi (2009) recounts how in the drafting of the convention, "the relationship to other international regimes was the most controversial issue." (p. 262.) One of the first drafts of the CCD offered two versions of a clause explaining the CCD's role in the hierarchy of international trade instruments (UNESCO, 2004). The first version, a two-part clause, stipulated that the UNESCO CCD may not be "interpreted as affecting the rights and obligations of the States Parties under any existing international instrument" two which they were parties, and either related specifically to intellectual property rights, or any 
other type of instrument, so long as "exercise of those rights and obligations would cause serious damage or threat to the diversity of cultural expressions" (UNESCO, 2004).

The second version was far less specific, stating only that "Nothing in this Convention shall affect the rights and obligations of the States Parties under any other existing international instruments." Argument over the two versions, which offered vastly differing views on the trade versus culture debate (one instilled some set of limitations on trade deals that dealt with cultural industries, while the other did not), resulted in a compromise in the final version that Choi (2009) describes as "rather bizarre": both versions were combined into a single, multipart clause, rendering either functionally meaningless.

As Burri-Nenova, Choi and others (Acheson \& Maule, 2006) (Hahn, 2006) have shown, commentary on the CCD has, till now, pointed out some of its potential legal flaws and attempted to predict what sort of outcome it will have as a document if employed as a trade tool. Examination of its employment itself, however is quite limited. This is in part because few examples of its citation in trade agreements and dispute resolution processes exist, and two significant instances of the former are relatively recent, having been signed in 2016 and 2017 respectively.

These issues with the CCD as they relate to culture and trade will be discussed in a short series of case studies following a discussion of the theoretical concepts at play here. But it is important to point out upfront a few similarities in where Canadian and international cultural policy approaches and the CCD stand on the concept of culture versus trade, and the limitations of such a stance. 
Both, as a look at Canada's Comprehensive Economic Trade Agreement with the European Union will show, have not found a way to assert the rights to protection of cultural diversity in any concrete form when negotiating trade deals. Due to a fundamental difference in the valuation of cultural goods and services, avenues for dispute resolution have proven, so far, to side on the favour of a negotiating party arguing the case of freer trade.

\section{Theoretical Framework: Culture and trade as theoretical loggerheads, or a two-} sided coin?

At the heart of Canada's history in international cultural policy and the existence of the CCD is the belief that cultural products and the industries they give rise to are conveyors of symbolism, meaning and identity — qualities that imbue them with intangible and unmeasurable, but nonetheless important, value. The insertion of this belief into an international trade regime, where the value of goods in every other instance is determined strictly on monetary terms, has for years been a source of contention, and is perhaps one of the most high-profile demonstrations of the awkward relationship between economic and cultural policy (Throsby, 2013).

It is precisely this uneasy relationship that makes the critical theory a useful for this research paper, and what informs the working hypothesis: that the CCD cannot be effective in countering market influences on culture when its valuation, profit, is the only marker for success. With roots in the Frankfurt School's conceptions of culture and the cultural industries (Adorno \& Horkheimer), this school of thought posits that 
culture and the products that make up its web of influence has an inherent, intangible social worth that is best left separate from systems of valuation and mass production.

This framework of this research paper does not take that conception of cultural valuation quite so far, however. Contemporary economists argue that measurable, financial policies and their impacts can constitute cultural ones, and vice versa; that both can be rendered a two-sided coin. University of Warwick Centre for Cultural Policy Studies director Jeremy Ahearne (2009) has written of the concept of explicit and nominal governance: that governmental policies should be understood as a means of manufacturing consent through enacting effects on the culture of the governed.

Moving this line of inquiry more squarely into the realm of free trade is Australian economist David Throsby's (2013) assertion that if explicit cultural policy is going to remain effective at fostering local cultures while enabling innovation, the governing bodies developing these policies will need to get comfortable with the idea of economic frameworks, while at the same time be willing to view cultural products and industries as having twin values, and valuation systems.

He writes: "it can be argued that creative artists in fact supply a dual market — a physical market for the good, which determines its economic price, and a market for ideas, which determines the good's cultural price.” (p. 21)

The CCD is best read as an explicitly cultural policy with economic implications. The trouble with such an approach, as previous scholars have pointed out, is its ineffectiveness when invoked in a purely economic framework that makes no other concessions for culture and demands a legal language that fits within its framework. 
As such, this approach all but guarantees that culture will still be relegated as secondary to free market forces.

\section{Research Method and Data}

This study's question - whether the CCD has proven effective as a tool to protect and promote cultural rights in global trade - centres on the document of the convention itself. Analyzing how it has been employed best lends itself to a case study model as the instances of its usage (or notable lack thereof) are relatively low in number, complex in nature, and not easily compared in a uniform fashion. The three case studies will cover two instances of the CCD being employed in contemporary free trade agreements, and one instance of its use in a trade conflict mediated by the World Trade Organization's dispute settlement arm.

Each case study will outline the context for the trade agreement or conflict; through the publicly available text of trade documents and WTO court proceedings (the data set), explain how the CCD is cited and employed; and conclude, using Throsby's framework of implicit/explicit cultural policy, with an evaluation whether such usage has had or can have any measurable impact on how culture is protected. A followup discussion will look at the study's limits, and suggestions for further research.

\section{Case Study One: WTO Dispute Settlement Redux}

Close to ten years to the month after the WTO's Dispute Settlement Body issued a ruling in favour of the United States against Canada on the case of split-run periodicals, China found itself in a similar situation with the WTO and U.S., this time 
regarding the importation and distribution of feature films, audiovisual services and published goods both print and digital (WTO, 2012). At the time, China was a newlysigned member state to the UNESCO CCD, and had maintained importation restrictions on all previously mentioned goods and services. Such material was either subject to specific types of review or in some cases mandated to be distributed by a Chinese-based enterprise - in effect requiring that such material be distributed by a state-owned body (WTO, 2007).

In mid-April, 2007, the United States issued a request for consultations to the WTO's Dispute Body over this perceived infraction of trade law (China is also a member of the WTO), stating that such measures "restrict market access for, or discriminate against, foreign suppliers of distribution services for publications and foreign suppliers of audiovisual services," and was in contravention to both its obligations to GATS and GATT commitments (WTO, 2007, p. 2). Considering the sharp uptick in Chinese cultural exports from 2004 onwards previously noted in the literature review, the United States' request for consultation is likely of little surprise. What was, unexpected, however, were two events during the unfolding of this dispute resolution: the arguments presented on the part of China, and the secondary parties that stepped up to support the United States in refuting them.

In WTO files documenting the preliminary hearings of the case, representation for China was noted as stating that "as vectors of identity, values and meaning, cultural goods play an essential role in the evolution and definition of elements such as societal features, values, ways of living together, ethics and behaviours," (WTO, 2009, pp. 751) arguing essentially that such measures of state-owned distribution and content review 
mechanisms were necessary to protect such values, and suggesting that doing so was in protection of national culture. A great deal might be argued as to what the effects of such rules - whether applied domestically or to international cultural trade — might have on freedom of expression as opposed to cultural diversity or expressions of it, but such a discussion is outside the scope of this study. What is highly relevant here is China's presentation of the UNESCO CCD as a form case law in support of their values and culture defence. At the time, and since then, it has been the only instance the Convention has been formally cited in a trade dispute.

In written submissions to the Dispute Settlement Body, trade representatives for China argued that "cultural goods are different from other non-cultural goods and that the Members preserve more leeway in regulating these goods." China further argued that, under Article XX of the GATT's general exemptions list, it was afforded the freedom to take on measures that were "necessary to protect public morals." (WTO, 2009, p. 86)

From a strictly functional point of view, this might have proven to be one potential arena for the $\mathrm{CCD}$ in practice: here was an argument suggesting that protectionist measures regarding the importation and distribution of cultural products was justified because (a) it supported a nation's view of what constituted protection of cultural expression and (b) it was also supported by an existing free trade agreement, which the CCD ceded authority to.

Within a year into proceedings, a number of signatory parties to the $\mathrm{CCD}-$ including Australia, South Korea, Japan and the EU — exercised third-party rights to participate in the resolution in support of the United States (WTO, 2009). Such 
eagerness to do so may have spoken more to those parties' view of China's characterization of public morals and how that related to diversity of local culture, but what is relevant here is the arguments made in support of the United States' case: that the CCD simply could not be used in such a forum, as it doesn't retain the legal clout to do so.

Representatives for Australia submitted as part of the proceedings that China had failed "to show that there exists a relationship between the cultural value of the items at issue, that is, between reading materials and audiovisual products, including sound recordings, and the standards of right and wrong conduct maintained in China," and furthermore had "ignored" the much-criticized Article 20 of the CCD, which limited its authority as a legal instrument in the face of trade agreements (WTO, 2009). Regardless of its views of GATT's Article XX, China was still contravention of WTO trade law.

Whereas such nations might have keenly watched the U.S. v. Canada proceedings at the WTO some ten years ago, that some of the CCD's earliest signatory parties would support a nation that originally protested the Convention by pointing out its flaws sends a message about not only what the CCD's legal limits are when tested, but what signatory parties see its role to be in the free trade landscape: decidedly not as a dispute resolution tool when it comes to trade. As the next two case studies will suggest, the convention's ability to remind state negotiators of the importance of recognizing the general concept of cultural diversity, expression and the protection of both at the trading table is celebrated, but not so much its ability to enforce or define during such talks - or after, in instances when conflict ensues. 
As cultural policy consultant Garry Neil pointed out in an assessment of the proceedings: "The strength of WTO agreements arises from the fact that States have made specific and concrete commitments to each other. If they fail to conform to these commitments, the dispute settlement system is obligatory and the decisions are enforceable. As a result of the WTO case, China will have no option but to bring its cultural policy measures into conformity" (Neil, 2014, p. 739). And such was the case: in 2010, after a number of appeals the WTO eventually did rule against China on every argument made in defence of its trade and distribution practices (WTO, 2010).

Seen one way, the outcome of this case might suggest that the CCD simply does not function as an explicitly economic policy. Its lack of obligations means that it cannot manufacture an outcome in instances of treaty-signed nations disagreeing on culture's appropriate place in trade in regards to a specific case; it is not a tool that directs. Furthermore, there is no established penalization system in the CCD for instances where two countries find themselves in disagreement over whether one is flouting the dictums of the convention in regards to free trade. What the following case study will attempt to discern is if the CCD's role lies more in the implicit, and whether or not it might be used as an interpretive tool, rather than a directive one.

\section{Case Study Two: The Canada-EU Comprehensive Economic Trade Agreement}

Legal scholar and UNESCO consultant Lillian Richieri Hanania (2014) identified a crucial — and not necessarily guaranteed - condition to the success of the CCD's operational effectiveness. "Due to the weak legal wording employed in the [CCD], compared to the usual binding language of trade agreements, the political will 
of the parties to take the $[\mathrm{CCD}]$ into account when negotiating new agreements becomes fundamental to its implementation," she wrote (p. 29). In the near decade since its launch, this willingness in proof has proved relatively rare. Indeed, Canada and the European Union — two of the keenest parties to will the convention into existence are currently the first, and among the very few, to have cited and implement the CCD into a negotiated trade agreement (Guévremont, 2017).

Negotiated over a five-year period that concluded in late 2014, the Comprehensive Economic and Trade Agreement between Canada and all member states of the European Union has been billed in federal publications about the negotiation proceedings as “one of Canada's most ambitious trade initiatives, setting new standards in the trade of goods and services, non-tariff barriers, investment, government procurement, as well as other areas like labour and environment." (Global Affairs Canada, 2017) In scope and length it is second only to NAFTA, which is currently under a contentious renegotiation.

CETA holds a particularly demonstrative place in analysing contemporary uses of the CCD in trade agreements because of its timing. Unlike the tariff-focused negotiations of the $80 \mathrm{~s}$ or the NAFTA-focused era of the $90 \mathrm{~s}$, this agreement qualifies as what Maria Trinidad and Garcia Leiva (2015) have called a truly second-generation free trade agreement — one that seeks to ameliorate trade barriers identified in standards, procedures and regulations that had not previously been addressed in the earlier two decades of the free trade era. As such, any successful application of the CCD here could potentially set an example for future trade agreements (with Canada, 
EU, or otherwise) that are starting to increase the frequency with which they negotiate FTAs.

When read for explicit mention, the CCD appears only once: in CETA's preamble, where over the course of one line the text lays out the Convention's role in the agreement.

"AFFIRMING their commitments as parties to the UNESCO [CCD]... and recognising that states have the right to preserve, develop and implement their cultural policies, to support their cultural industries for the purpose of strengthening the diversity of cultural expressions, and to preserve their cultural identity, including through the use of regulatory measures and financial support” (CETA, 2016)

In spirit, this is significant, as it renders CETA the only completed free trade agreement Canada has negotiated to date with formal inclusion of the CCD in its provisions (Coalition for Cultural Diversity, 2013). Understanding how this works in practice, however, requires a thorough look at any Article of CETA that handles issues of trade exemptions, limitations or restrictions as it relates to cultural activity and industry, as the Convention is not explicitly invoked anywhere else to support its stipulations and, as previously noted, does not include any set of strong obligations that would pre-emptively suggest how any particular section of the agreement may have been handled.

The first instance where the rights vs. obligations issue becomes clear in document's set of definitions, and how those definitions are employed in various parts throughout the agreement. Canada and the EU seem to differ on not so much the idea of what "cultural industries" are in the context of a free trade agreement - these are laid 
out clearly in Article 1.1 in a specific and comprehensive five-point list that includes the arenas of publishing, film, audio-video music recordings, published music, and broadcasting of radio or television (CETA, 2016).

This definition, however, is not uniformly applied. Article 7.7, on exemptions to rules around information disclosure and consultation expectations on subsidies that have the potential to negatively affect trade reads as such: "Nothing in this Agreement applies to subsidies or government support with respect to audio-visual services for the European Union and to cultural industries for Canada." Similar language is used in Article 8.2, in regards to the scope of application to trade on investment; again in Article 9.2, for exemptions to stipulations on cross-border trade; and a fourth time in Article 12.2, regarding domestic regulation. In nearly every instance where culture's role in - or consideration for exemption from - trade is mentioned in CETA, EU and Canada employ a different definition of what this is, a right explicitly granted by the CCD itself.

In other words, CETA has functioned as the same pen for both parties to draw their visions for how cultural industries and cultural expression figures into a free-trade system, and while Canada has chosen a broader-ranging list, the EU has gone with a description of audio-visual services that Leiva and Garcia (2015) have pointed out is narrower and quite different from that of the internationally accepted WTO standard. It is also interesting to note that in an agreement that covers nearly thirty sectors of industry, only five chapters (the four previously noted, including Article 19 on government procurement) include any type of mention of cultural exemption; they are 
the only instances in this document where one may argue the CCD's granted rights to protection may have been employed.

The second problem is with legal cohesiveness. In terms of overall exemptions, both Canada and the EU agreed to import Article XX (f) of the GATT, a clause includes a separate description cultural exemptions, one that limits its scope to "national treasures of artistic, historic or archaeological value" (GATT, 1994) In other words, not only are cultural industries as they are understood in a contemporary sense not defined, but neither are some of the vehicles via which such culture is produced.

This leads to the third, and potentially ongoing issue with how culture figures into CETA, one that the CCD has not seemed to address: exemptions in every previous article cited takes a "negative list" approach, meaning that no exemption clauses apply overall to the document.

Unless specifically noted — or listed — they are not necessarily subject to protections from free trade agreements. While this has potentially troubling implications for, say, public services, it also means that the need for detailed specification leaves cultural industries or modes of cultural production not yet extant or economically significant vulnerable to trade influence in the future. (Maltais, 2014)

Returning to Throsby's framework of implicit-explicit cultural policy effects, it is important to note sections of CETA that, while not explicitly referencing cultural exemptions or industries of any kind, could potentially have an effect on either category. A notable one includes investor-state dispute settlement, a much-protested mechanism of the agreement included in its chapter on investment (CETA, 2016) that allows foreign investors an unprecedented level of privilege in their ability to sue host 
governments for rights or punitive compensations regarding a wide range of statesanctioned actions perceived to be either unfairly damaging to foreign investors' ability to operate in such districts, discriminatory treatment, flouting market access rules, and more (Fuchs, 2014). Such grievances may also be made without use of domestic judicial systems or independent courts.

Naturally, such conditions of an agreement have proven to be controversial for the many areas of industry it might affect. As Michael Geist pointed out in 2016, foreign investor and local-government clashes in the arenas of pharmaceutical patents and mining interests that have already manifested themselves prior to the signing of CETA that year will likely be exacerbated as a result (Geist, 2016).

That it comes at a time, however, when the current federal government is hosting a public review of its cultural policies regarding properties, including The Broadcast Act, CanCon stipulations and foreign ownership policies (Heritage Canada, 2017), is potentially troublesome. Canadian publishing, for example, has already begun to see signs of ownership concentration that stem back to the late 2000 s, from AG Bertelsmann purchasing and acquiring heritage publisher McClelland \& Stewart in 2011 (Barber, 2012), to U.S. publishers Simon \& Schuster being among the first major foreign publishers allowed the opportunity to sign and originate book deals with Canadian authors, for a Canadian market (Houpt, 2013).

In conclusion, considering its status as the first free trade agreement to include it in its text, one may identify two significant contributions that the UNESCO CCD has had on trade negotiations thus far. First, that it allows negotiating parties a mutually agreeable touchstone upon which to state intentions of negotiating cultural exemptions 
in an FTA, and that it is flexible enough to allow negotiating parties to define what such terms mean in the context of their own political needs. However, as previous commentators have noted, it is also a missed opportunity in providing legally binding language or stipulations - and its ambiguity in application in the case of CETA could potentially set unhelpful examples for trading partners who wish to employ it in the future, as the final case study will suggest.

\section{Case Study Three: The CPPTPP}

The Comprehensive and Progressive Agreement for Trans-Pacific Partnership (CPTPP) is an 11-party free trade agreement that began as the expansion of a smaller multi-lateral agreement between Brunei, Chile, New Zealand and Singapore. It renewed its negotiations this year after, at the behest of its then-newly elected president, the sudden exit of the United States in 2017, and currently has a non-ratified, consolidated agreement text modified by a short set of updates to the original, pre 2018 document (CPTPP, 2018). It is expected to enter into force within the first half of 2019. Once this happens, it will rival only CETA in terms of its breadth and scope of international influence.

As such, concern over the CPTPP as regards Canadian cultural policy is not insignificant. Prior to the United States' withdrawal from the multilateral deal, the original text of the TPP did not include an overall or even gestural exemption for cultural industries (TPP, 2015) and nor does its updated CPTPP preamble, unlike CETA and a number of Canadian free trade agreements preceding it. Notably, a citation for the UNESCO CCD is nowhere to be found. Since the renewal of CPTPP talks and the 
completion of the agreement's consolidated text, however, two important developments signal a turn towards cultural exemptions that may only have been possible since the United States' swift exit from the trade talks.

The first is a set of four annexes added to the agreement since 2016. Two of them, cross-border trade and state-owned enterprises, make mention of cultural industries as being exempt from any provision that might prevent the state from making restrictions for cultural industries (which are defined similarly to CETAs), and in particular audiovisual services (CPTPP, 2017). Considering the relative scramble implied over the last 18 months to push through this trade agreement in light of the U.S. exit, such an approach makes sense, though relegating cultural industries as a whole to an annex format as a "non-conforming measure" renders its stipulations as secondary to the terms of the agreement, which some legal experts have stated does not hold the same clout as a formal exemption.

The second, and perhaps more important, are a series of side letter agreements made with each participating party to the trade agreement regarding the domestic regulation of audio-visual services. They suggest that the current Canadian government is very interested in retaining the ability to leverage domestic exemption or protectionist-like policies regarding online streaming audio-visual streaming services, and without the moral or legal support of the CCD.

Released in March of 2018, these side letter agreements constitute a written agreement with every other participant in the CPTPP and stipulate that "Canada may adopt or maintain discriminatory requirements on service suppliers or investors to make 
financial contributions for Canadian content development and may adopt or maintain measures that restrict access to on-line foreign audio-visual content" (CPTPP, 2017).

While similar to the CPTPP's annexes these side letters might be seen as legally subordinate to the primary text of the agreement, they are notable for their specificity, their recognition of an ascendant area of cultural industry heretofore not previously noted in trade agreements, and for their potential to re-invigorate an national discussion regarding the place of cultural policy in the telecommunications arena.

At political issue in this moment is the prospect of what has been popularly called the "Netflix tax": the question of what to do with foreign audio-visual streaming services such as Netflix which, unlike domestic services such as the now-defunct Shomi and CraveTV, enjoy deep market penetration in a growing arena and are subject to virtually no trade stipulations or domestic policy regulation. While there are a number of options available to government at the moment - enforced HST collection, a CanCon fee, the lifting of tax collection requirements for domestic streaming companies — the prospect of enforcing any has come with a controversial price tag.

In the language of politicians and media alike, the prospect of taxing Canadian citizens for access to a type of entertainment service that has already been readily available domestically for years has come to be seen as something of a telecommunications access concern (Jackson, 2018). However, the fact that that federal representatives felt it necessary to negotiate such a side instrument indicates some level of willingness to insist on at least considering building some sort of a policy in the future. Should one ever be imposed, how such a tax or tariff be employed could determine whether it is seen as an explicitly cultural policy (i.e. a fee put towards 
production of Canadian content versus a general sales tax), but as a trade stipulation, it is still a significant cultural concession —one negotiated without a CCD citation.

That last point is a significant takeaway from both these developments in the provisional wording of this final CPTPP agreement. Compared to CETA, it is stronger and more specific in its language regarding cultural exemptions, and its negotiating parties have managed to achieve this without any formal acknowledgement of the CCD or its potential role in influencing any kind of concessions. And, unlike the China-U.S. trade dispute case discussed earlier, should any conflict between signatory parties arise regarding, say, a perceived contravention of a side instrument regarding streaming audiovisual services, there is an actionable document a party can bring to a dispute resolution body that is far more likely to hold legal weight.

\section{Discussion and Conclusion}

Three case studies - a close read of a WTO dispute resolution body decision and two separate free trade agreement texts — have shown that in both trade law and trade disputes the CCD does not carry the clout required to allow nations to make trade agreement frameworks they feel necessary to protect local cultural industry. In some ways, this can be seen as a shortfall: to say that the way in which federal negotiators handle the issue of culture and free trade with CETA and the CPTPP could have ramifications on the future of culture's place in free trade agreements globally is no small judgment; particularly with CETA, which entered into force as of 2017, it will be interesting to see how trade disputes regarding, say, foreign ownership in a cultural industry arena, are mediated should any arise in the near future. 
A study of this nature is, of course, subject to limitations. Without access to earlier drafts of CETA or the CPTPP, as was the case for the text of the UNESCO CCD, there are likely trade disagreements and compromises that will have gone unexamined. It's unknown if, for example, a participant in CPTPP talks brought up the possibility of inserting the CCD into the agreement's text the way it was employed in CETA — or if its insertion may be precisely the reason why it was avoided in this case.

This study also focuses specifically on examining the CCD as a legal instrument; as scholars such as Mira Burri (2008) and Christopher Beat Graber (2008) have suggested, considering the $\mathrm{CCD}$ as an organizing tool rather than a legal instrument might offer an opportunity to focus on the ways in which it has helped certain countries establish richer domestic cultural policy frameworks.

It might also encourage future study on how nations such as Canada — who have, as these looks at CETA and the CPTPP have shown, have maintained some willingness to keep culture on the agenda on the trading table — may employ existing trade law in ways that better address the trade/culture divide, or as the CPTPP side instrument noted exemplifies, focus on better understanding how digital cultural industry fits into the free trade, a long-overdue discussion that is increasingly becoming not only relevant, but necessary.

To date, Canada is in negotiations for 14 free trade agreements with nations around the world; another 12 are under consideration for the future, making it second only to the EU in terms of trade negotiations volume (Guevremont, 2017). Between this; the turbulent nature of the current re-negotiation of NAFTA; and Creative Canada, the federal government's initiative to re-haul its cultural policy framework for the 
digital age, we are clearly headed towards another crucial moment in Canada's role in the free trade and culture relationship.

In considering the future, perhaps it is more useful to re-imagine the function the CCD might have in how we position ourselves as a trading nation that also values the culture it produces; to focus less on its citation, and instead operate in the spirit of its purpose when negotiating cultural exceptions, or defining what they mean to begin with; to use it as an interpretive tool for how cultural policy frameworks are developed domestically, particularly in regards to digital properties. In other words, to imagine what the future of Canadian cultural policy itself should look like. As the past has shown us, both their fates are linked. 


\section{References}

Acheson, K., \& Maule, C. (2002). Much ado about culture: North American trade disputes. University of Michigan Press.

Acheson, K., \& Maule, C. (2004). Convention on Cultural Diversity. Journal of Cultural Economics, 28(4), 243-256. doi:10.1007/s10824-004-3587-9

Adams, J. (2010, January 20). New Rules ‘a Big, Big Hit’ to Canadian Magazines. The Globe and Mail.

Adorno, T. (2016). The Culture Industries. In M. Horkheimer (Ed.), The Dialectic of Enlightenment. Verso Books.

Ahearne, J. (2009). Cultural policy explicit and implicit: A distinction and some uses. International Journal of Cultural Policy, 15(2), 141-153. doi: $10.1080 / 10286630902746245$

Armstrong, S. (2000). Magazines, Cultural Policy and Globalization: The Forced Retreat of the State? Canadian Public Policy / Analyse De Politiques, 26(3), 369. doi:10.2307/3552407

Aylett, H. (2010). An international instrument for international cultural policy. International Journal of Cultural Studies, 13(4), 355-373. doi:10.1177/1367877910369975

Belanger, L. (1999). Redefining Cultural Diplomacy: Cultural Security and Foreign Policy in Canada. Political Psychology, 20(4), 677-699. doi:10.1111/0162$895 x .00164$

Burri-Nenova, M. (2008). Trade versus Culture in the Digital Environment: An Old Conflict in Need of a New Definition. Journal of International Economic Law, 
12(1), 17-62. doi:10.1093/jiel/jgn038

Canada, Parliament of Canada. (n.d.). Bill C-103: An Act to Amend The Excise Tax Act And The Income Act.

Canada House of Commons, and Clifford Lincoln. "A Sense of Place - A Sense of Being.” Canadian Standing Committee on Heritage, 1999.

"Chapter Eight: Investment." (2017) Text of the Comprehensive Economic and Trade Agreement, Government of Canada. Retrieved from: international.gc.ca/tradecommerce/trade-agreements-accords-commerciaux/agr-acc/ceta-aecg/texttexte/08.aspx?lang=eng.

“Chapter One: General Definitions and Initial Provisions." (2017) Text of the Comprehensive Economic and Trade Agreement, Government of Canada. Retrieved from international.gc.ca/trade-commerce/trade-agreements-accordscommerciaux/agr-acc/ceta-aecg/texttexte/01.aspx?lang=eng.

"China — Measures Affecting Trading Rights and Distribution Services for Certain Publications and Audiovisual Entertainment Products.” (2012) Dispute Settlement DS363, World Trade Organization. Retrieved from www.wto.org/english/tratop e/dispu e/cases e/ds363 e.htm.

Choi, B. (2009). Trade Barriers or Cultural Diversity? In W. J. Drake \& E. J. Wilson (Authors), Governing global electronic networks: International perspectives on policy and power. Cambridge, MA: MIT Press.

Coalition for Cultural Diversity. "Cultural exemption: reaching an agreement with the Europeans." (2013) Retrieved from: http://www.cdc-ccd.org/Exemption-culturelle- 
trouverun?lang=en.

Conlogue, R. (2001, June 11). “Ottawa’s Plans to Guard Our Culture.” The Globe and Mail.Convention on the Protection and Promotion of the Diversity of Cultural Expressions. (2008) Diversity of Cultural Expressions, UNESCO. Retrieved from en.unesco.org/creativity/convention.

Cummings, M. C., \& Katz, R. S. (1987). Patron state: Government and the arts in Europe, North America, and Japan. New York, NY: Oxford University Press.

“DS31: Canada - Certain Measures Concerning Periodicals." (2008) WTO Dispute Settlement. Retrieved from www.wto.org/english/tratop_e/dispu_e/cases_e/ ds31_e.htm.

Debray, R., \& Howe, J. (2007). Praised be our lords: A political education. London: Verso Books.

Department of Communications, et al. "Report of the Federal Cultural Policy Review Committee.” (1982) Minister of Supply and Services Canada.

Dubinsky, L. (1996). Periodical Publishing. In M. Dorland (Author), The Cultural Industries in Canada: Problems, policies and prospects. Toronto, ON:

J.Lorimer.Fuchs, P. (2014). Investor-State Dispute Settlement. In S. Sinclair, S. Trew, \& H. Mertins-Kirkwood (Authors), Making sense of the CETA: An analysis of the final text of the Canada-European Union Comprehensive Economic and Trade Agreement. Ottawa, ON: Canadian Centre for Policy Alternatives. Government of Canada, Global Affairs Canada, Deputy Minister of Foreign Affairs. “Agreement Overview." (2017) Retrieved from international.gc.ca/tradecommerce/tradeagreements-accords-commerciaux/agr-acc/ceta-aecg/overview- 
apercu.aspx?lang=eng.

Guévremont, Véronique. "The Convention in Other International Forums: A Crucial Commitment.” (2017) 2005 Convention Global Report, 3rd ed., pp. 143-161.

Geist, M. (2016, October 5). The Devil's in CETA's Details, Specifically on Dispute Settlement. The Globe and Mail.

General Conference, 33rd Session, UNESCO. “General Conference Adopts Convention on the Protection and Promotion of the Diversity of Cultural Expressions.” (2005) Retrieved from portal.unesco.org/en/ev.phpURL_ID=30297\&URL_DO= DO TOPIC\&URL SECTION=201.html.

Granville, K. (2017, January 23). What Is TPP? Behind the Trade Deal That Died. The New York Times.

Hahn, M. (2006). A Clash of Cultures? The UNESCO Diversity Convention and International Trade Law. Journal of International Economic Law, 9(3), 515-552. doi:10.1093/jiel/jgl021

Hanania, L. R. (2016). Effects of the CDCE On Trade Negotiations. In Cultural diversity in international law: The effectiveness of the UNESCO Convention on the Protection and Promotion of the Diversity of Cultural Expressions (p. 29). London: Routledge.

Heritage, Canadian. “Creative Canada - A Vision for Canada's Creative Industries." (2017) Retrieved from www.canada.ca/en/canadianheritage/campaigns/creativecanada.html.

Houpt, S. (2013, January 23). Canada's Elastic Policy on Foreign Publishers. The Globe and Mail. 
Leiva, M. T. (2015). Cultural diversity and free trade: The case of the EU-Canada agreement. International Journal of Cultural Policy, 23(6), 765-781. doi: $10.1080 / 10286632.2015 .1119131$

Maltais, A. (2014). "Making Sense of the CETA. An analysis of the Final Text of the Canada-European Union Comprehensive Economic and Trade Agreement.” (Rep.). Toronto: Canadian Centre for Policy Alternatives.

Neathery-Castro, J. (2012). Canada as multilateral player: Trade in cultural products. Canadian Foreign Policy Journal, 18(1), 76-91. doi:

$10.1080 / 11926422.2012 .674377$

Naoto, Jinji. (2015) “How Does UNESCO’s Convention on Cultural Diversity Affect Trade in Cultural Goods?” RIETI.

Neil, G. (2014). Conclusions: Perspectives and Challenges for the Convention. In S. V. Schorlemer \& P. Stoll (Authors), The UNESCO Convention on the Protection and Promotion of the Diversity of Cultural Expressions Explanatory Notes (pp. 739-749). Berlin: Springer Berlin.

Riding, A. (2005, October 15). U.S. Stands Alone in UNESCO Cultural Issue. The New York Times.

Schorlemer, S. V., \& Stoll, P. (2014). Introduction. In The UNESCO Convention on the Protection and Promotion of the Diversity of Cultural Expressions Explanatory Notes (pp. 14-15). Berlin: Springer Berlin.

Text of the General Agreement on Tariffs and Trade (1994) p. 38. Retrieved from https://www.wto.org/english/docs_e/legal_e/gatt47_e.pdf 
UNESCO (2016) The Globalisation of Cultural Trade. Retrieved from uis.unesco.org/sites/default/files/documents/the-globalisation-of-cultural-tradea-shift-in-consumption-international-flows-of-cultural-goods-services-20042013-en 0.pdf.

Throsby, C. D. (2013). International Trade. In The economics of cultural policy (pp. 157-169). Cambridge, MA: Cambridge University Press.

Throsby, C. D. (2013). Value and Valuation. In The economics of cultural policy (pp. 14-25). Cambridge, MA: Cambridge University Press.

Global Affairs Canada (2017) Trade and Investment Agreements. Retrieved from www.international.gc.ca/trade-commerce/trade-agreements-accordscommerciaux/agr-acc/index.aspx?lang=eng.

European Union, Government of Canada. (2016) Text of the Comprehensive Economic and Trade Agreement-Preamble. Retrieved from international.gc.ca/tradecommerce/trade-agreements-accords-commerciaux/agr-acc/ceta-aecg/texttexte/PRE.aspx?lang=eng.

Office of the United States Trade Representative. (2015). Trans-Pacific Partnership Full Text. Retrieved from ustr.gov/trade-agreements/free-trade-agreements/transpacific-partnership/tpp-full-text. Annex II (d)

WTO (2007). Request for Consultations, China - Measures affecting trading rights and distribution services for certain publications and audiovisual entertainment products, WTO Doc. WT/DS363/1, G/L/820, S/L/287 of 16 April 2007.

Zemans, J. (1997). Canadian Cultural Policy in a Globalized World. Canadian Review of American Studies, 27(3), 111-126. doi:10.3138/cras-027-03-08 